\title{
The Constitutionality of §89a Ila of the German Criminal Code and the Concept of a Serious Violent Offense Endangering the State: The German Federal Court of Justice Decision of April 6, 2017-3 StR 326/16
}

\author{
Anne-Sophie Zaunseder* and Michelle Heblik**
}

(Accepted 27 September 2019)

\begin{abstract}
This Article discusses the constitutionality of the recently implemented $\$ 89$ a IIa of the German Criminal Code (Strafgesetzbuch-StGB) on the basis of the case 3 StR 326/16 decided by the Federal Court of Justice (BGH) on April 6, 2017. First, this Article introduces $₫ 89$ a IIa of the StGB with a short summary of the events leading to the present anti-terrorist legislation in Germany and the development of the legislation over the past few decades. Second, the facts of the BGH's case will be outlined, and an overview of the systematic structure of $\$ 89$ a I, II No. 1, IIa StGB will be provided. Within this framework, the constitutionality of $\$ 89$ a IIa StGB will be discussed, focusing on the prerequisite of appropriateness, with special attention paid to the requirement of reasonability and the prerequisite of legal certainty pursuant to Article 103(II) Basic Law (Grundgesetz-GG). Finally, $₫ 89$ a I, II No. 1, IIa StGB will be applied to the BGH's case after discussing the contentious legal issues regarding these doctrines. This Article concludes by discussing the BGH’s decision, which deems $₫ 89$ a IIa StGB to be constitutional.
\end{abstract}

Keywords: Serious violent offense endangering the state; foreign fighters; constitutionality; German Federal Court of Justice; $\$$ 89a IIa German Criminal Code

\section{A. Introduction}

In 1976, $\$ 129 \mathrm{a} \mathrm{StGB}^{1}$ was implemented by way of the anti-terror laws owing to the increasing number of terrorist acts of violence. ${ }^{2}$ In the face of the notorious terrorist attacks on September 11, 2001, \$129a StGB was fundamentally amended and $\$ 129$ b StGB was implemented. ${ }^{3}$ Participating

${ }^{\star}$ Anne-Sophie Zaunseder is currently a student of law at the Friedrich-Alexander Universität Erlangen-Nürnberg (FAU Erlangen-Nürnberg) and is about to finish her law studies, which focus on the fields of European and International law, she is also participating in an extracurricular advanced English Legal Language program. She wishes to thank Dr. Kevin Pike and Prof. Dr. Christoph Safferling for their help and the opportunity to develop this article.

${ }^{* *}$ Michelle Heblik is currently a student of law at the Friedrich-Alexander Universität Erlangen-Nürnberg she is especially interested in criminal law and animal protection law. She partakes in the extracurricular advanced English Legal Language program of the FAU Erlangen-Nürnberg and she wishes to thank Dr. Kevin Pike and Prof. Dr. Christoph Safferling for their help and the opportunity to develop this article.

${ }^{1}$ StrafgesetzBuch [StGB] [Penal Code], translation at https://www.gesetze-im-internet.de/stgb/index.html (Ger.).

${ }^{2}$ See Heribert Ostendorf, Kindhäuser/Neumann/Paeffgen Kommentar zum StGB, $\$ 129$ (b) para. 2 (5th ed. 2017).

${ }^{3}$ See Gesetzesentwurf [Draft Bill], Deutscher BundestaG: DrucKsaCHEN [BT] 15/813 at 1 (Ger.). 
in foreign terrorist organizations within the Federal Republic of Germany and establishing and participating in domestic terrorist organizations became a criminal offense pursuant to $\$ 129 \mathrm{~b} \mathrm{StGB}{ }^{4}$

In the aftermath of the terrorist attacks in London and Madrid, the foiled attacks on several aircraft in London, and the suitcase bombs detected in regional trains in Koblenz and Dortmund, German legislators felt the need for stricter regulations. The new regulations needed to close the criminal liability loophole open to terrorists who performed acts in preparation for an offense. Previously, these criminals, for want of a verifiably existing terrorist organization, were not indictable pursuant to $\$ 129$ a StGB for participating in or assisting within a terrorist organization. ${ }^{5}$ In addition to the legislators' preoccupations about further attacks on the sovereign territory of the Federal Republic of Germany, especially with regard to the thwarted bomb attacks of the so-called Sauerland-Gruppe, they were likewise concerned about further attacks within Europe. ${ }^{6}$ To counter the threats arising from serious violent offenses endangering the state, $₫ 89$ a StGB was implemented into the German Criminal Code in 2009. ${ }^{7}$

The United Nations resolution 2178 (2014) deems international terrorism, irrespective of other crimes, one of the greatest threats to global peace and international security, in addition to condemning all terrorist acts as unjustifiable and criminal. ${ }^{8}$ The UN Security Council noted, with great anxiety, that the terrorist threat has increased in various regions around the world. ${ }^{9}$ In the face of this heightened endangerment, particularly with respect to foreign terrorist fighters, the Council defined these terrorists as:

[N]amely individuals who travel to a State other than their States of residence or nationality for the purpose of the perpetration, planning, or preparation of, or participation in, terrorist acts or the providing or receiving of terrorist training, including in connection with armed conflict. $^{10}$

The UN-Security Council requires its member states to ensure the prosecution and punishment of these foreign fighters, if necessary by way of a legislative change to domestic laws. ${ }^{11}$

The German legislature acknowledged the threat that foreign terrorist fighters pose to the lives of innocent people and to the liberal-democratic constitution, expressly mentioning foreign fighters originating from Europe or even Germany. ${ }^{12}$

To supplement the existing criminal offenses-including the offense of preparing a serious violent act endangering the state in $\$ 89$ a StGB, the offense of establishing contacts for the purpose of committing a serious violent offense endangering the state in $\$ 89 \mathrm{~b}$ StGB, and the offense of encouraging the commission of a serious violent offense endangering the state in $\$ 91 \mathrm{StGB}$ - a bill to implement $\$ 89$ a IIa StGB ${ }^{13}$ was introduced and passed in 2015. It incorporates into the StGB

\footnotetext{
${ }^{4}$ See OSTENDORF, supra note 2 , at $\$ 129$ (b) para. 2.

${ }^{5}$ See Gesetzesentwurf [Draft Bill], Deutscher Bundestag: Drucksachen [BT] 16/11735 at 1-2 (Ger).

${ }^{6} \mathrm{See}$ id. at 1.

${ }^{7}$ See Bundesgesetzblatt, Teil I [BGBl I] [Federal Law Gazette], Part I Volume 2009 Nr. 49.

${ }^{8}$ See S.C. Res. 2178, 1 (Sept. 24, 2014).

${ }^{9}$ See id.

${ }^{10}$ See id. at 2.

${ }^{11}$ See id. at $4-5$.

${ }^{12} \mathrm{See}$ Gesetzesentwurf [Draft Bill], Deutscher Bundestag: DrucKsachen [BT] 18/4087 at 6 (Ger.).

${ }^{13}$ Strafgesetzbuch [StGB] [Penal Code], $\$ 89$ (a) IIa StGB:
}

Subsection (1) shall also be applicable if the offender prepares a serious violent act endangering the state by taking steps to leave the Federal Republic of Germany in order to move to a state within whose territory instructions by persons referred to in subsection (2) No. 1 are given and does so for the purpose of committing a serious violent offence endangering the state or for the purpose of committing any act mentioned under subsection (2) No. 1 hereof. 
the offense of committing a serious violent offense endangering the state by way of leaving or attempting to leave the Federal Republic of Germany for the purpose of the commission of a terrorist act or its preparation. ${ }^{14}$

Sections $89 \mathrm{a}$ and $\mathrm{b}$, as well as $\$ \$ 129 \mathrm{a}$ and b StGB, still regularly occupy the German courts. They function to protect against an increased risk of terrorist attacks, particularly perpetrated by foreign fighters. The following series of cases illustrate this: A court order issued by the BGH to extend the pre-trial detention of a remand prisoner who allegedly infringed $\$ \$ 89 \mathrm{a}$ I, II No. 1, 129a I, II, and 129b I StGB by participating in a terrorist organization, namely the Jabhat Fath al-Sham in Syria. ${ }^{15}$ He perpetrated said offenses by participating as a member and by planning a serious violent offense endangering the state, by virtue of the fact that the accused underwent several weeks of combat training and afterwards fought for Jabhat Fath al-Sham in Aleppo. ${ }^{16}$ In another decision, the BGH dismissed the appeal of a defendant who had been convicted for the preparation of a serious violent offense against the state pursuant to $\$ 89$ a II No. 1 StGB. In that case, the accused had been in contact with members of the Islamic State by means of chat messages, and, during these periods of contact, was instructed in the production of explosives for the purpose of implementing the accused's plan of using a homemade bomb to perpetrate an attack in Cologne. ${ }^{17}$

In another case involving $₫$ 89a IIa StGB in conjunction with $₫ 89$ a I, II No. 1 StGB, the constitutionality of $\$ 89$ a IIa StGB was questioned. Consequently, the constitutionality of $\$ 89$ a IIa StGB is presently at issue. This Article will address question of the constitutionality of $₫$ 89a IIa StGB on the basis of the BGH's decision from April 6, 2017. ${ }^{18}$

\section{B. Circumstances of the Decision}

Pursuant to the findings of the Regional Court of Munich, the accused was a German citizen domiciled in Munich and an adherent of an extremist Islamic ideology. The Court also found that the accused maintained connections with people from the Salafist scene who regard the participation in the armed combat in Syria against the al-Assad regime as a pivotal commitment. The accused believed the armed jihad to be a legitimate tool to enforce ultraconservative Islamist interests. Additionally, the accused rejected the values of the liberal-democratic constitution.

On June 24, 2015, the accused flew from Munich to Ankara, Turkey. He intended to continue his journey from Turkey to Syria. When the Turkish authorities refused to permit the accused to cross the Turkish-Syrian border, the accused returned to Munich on June 26, 2015. On October 10, 2015, the accused was apprehended at Munich Airport after passing through security and immigration controls. The accused intended to fly to Adana via Istanbul. From Adana, he once again intended to cross into Syria. At the time of his detention, the accused was in possession of a one-way ticket and was carrying outdoor clothing in mint condition, worth several hundred euros, two mobile phones, and 270 euros in cash. Some of the garments were items of clothing similar to those worn by soldiers in desert areas.

The accused's intent was to actively partake in armed combat operations in Syria on behalf of the jihad. For this purpose, the accused planned to be initially instructed in how to deal with firearms and explosives. Upon completion of his training, the accused was determined to participate in combat operations in Syria as a member of an Islamist organization, allegedly the Jabhat al-Nusra, or another organization that cooperates with the Jabhat al-Nusra group. The aim of

\footnotetext{
${ }^{14}$ See Gesetzesentwurf [Draft Bill], Deutscher Bundestag: DrucKsaChen [BT] 18/4087 at 6 (Ger.).

${ }^{15}$ Bundesgerichtshof [BGH] [Federal Court of Justice] Nov. 8, 2017, Neue Zeitschrift FÜr STrafrecht NStZRECHTSPRECHUNGS-REPORT STRAFRECHT [NStZRR] 42, 2018 (Ger.).

${ }^{16} I d$.

${ }^{17}$ Bundesgerichtshof [BGH] [Federal Court of Justice] Sept. 19, 2017, 28 NEUE ZEITSCHRIFT Für STRAFRECHT [NStZ] 89, 2008 (Ger.).

${ }^{18}$ Bundesgerichtshof [BGH] [Federal Court of Justice] Apr. 6, 2017, 70 NeUE JURISTISCHE WoCHENSCHRIFT [NJW] 2928, 2017 (Ger.).
} 
Jabhat al-Nusra and the other cooperating groups is, on the one hand, to destroy the state of Syria in its present form and, on the other hand, to establish a Sunnite Islamic theocratic state under the provisions of the sharia. ${ }^{19}$

The first-instance court, the Regional Court of Munich, convicted the accused of two counts of the preparation of a serious violent offense endangering the state under $₫ 89$ a IIa StGB in conjunction with $\$ 89$ a I, II No. 1 StGB. He was sentenced to a combined term of imprisonment of two years and six months. ${ }^{20}$ The accused then appealed the judgment of the Regional Court of Munich, based primarily upon a challenge to the proceedings and the breach of substantive law. The essence of the appeal was that $\$ 89$ a I, II No. 1 II a StGB is unconstitutional. ${ }^{21}$

\section{Decision of the BGH}

The BGH upheld the decision of the Regional Court of Munich as, in its opinion, it contained no error of law and the accused was therefore guilty of two offenses under $\$ 89$ a IIa StGB, in conjunction with $₫ 89$ a I, II No. 1 StGB. ${ }^{22}$ The accused committed the first offense on June 24, 2015. Owing to his successful departure from the Federal Republic of Germany and despite his failure to leave the sovereign territory of the Federal Republic of Germany on October 10,2015, his conduct sufficiently constituted an attempt. It also constituted the second violation of $\$ 89$ a IIa StGB in conjunction with $\$ 89$ a I, II No.1 StGB. ${ }^{23}$ Notwithstanding this, in the verdict at issue, the $\mathrm{BGH}$ addressed the constitutionality of the relevant sections: Sections $89 \mathrm{a}$ I, II No. 1 IIa StGB. ${ }^{24}$

In the following parts, the legal prerequisites of $\$ 89$ a I, II No. 1, IIa StGB will be addressed, followed by the BGH's assessment of the constitutionality of $₫ 89$ a I, II No. 1, IIa StGB, and the application to the instant case.

\section{The Legal Prerequisites of $\S 89 a$ I, II No. 1, II a StGB}

The legal prerequisites of the offense pursuant to $\$ 89$ a I, II No. 1, IIa StGB-an abstract endangerment offense ${ }^{25}$ - penalizes dangerous acts regardless of actual endangerment of a legally protected right. ${ }^{26}$ Abstract endangerment offenses are divided into subjective legal prerequisites_mens rea-and objective legal prerequisites-actus reus.

\section{Objective Legal Prerequisites (Actus Reus)}

Criminal wrongdoing is comprised of preparatory acts specified in $\$ 89$ a II, IIa StGB. These acts must serve the preparation of a serious violent offense endangering the state in accordance with $\$ 89 \mathrm{a}$ I StGB. ${ }^{27}$

\subsection{A Serious Violent Offense Endangering the State Pursuant to § 89 a I StGB}

Pursuant to the statutory definition of a serious violent offense endangering the state in $\$ 89 \mathrm{a}$ I 2 StGB, an offense against life under $\$ 211$ or $\$ 212$ or against personal freedom under $\$ 239$ a or

\footnotetext{
${ }^{19} I$ d. at paras. $1-3$.

${ }^{20}$ Landgericht München [LG München] [Regional Court Munich] Case No. 2 KLs 111 Js 169510/15 BECKRS 125005 (May 19, 2016).

${ }^{21} 70$ NJW 2928 at para. 4.

${ }^{22} I d$. at para. 5 .

${ }^{23} \mathrm{Id}$. at para. 7.

${ }^{24} \mathrm{Id}$. at paras. $25-40$.

${ }^{25}$ See Bernd von Heintschel-Heinegg, von Heintschel-Heinegg Strafgesetzbuch StGB Kommentar $\$ 89$ (a) para. 4 (37th ed. 2018).

${ }^{26}$ See Helmut Frister, Frister Strafrecht Allgemeiner Teil Studienbuch Ch. 3, para. 24 (C.H. Beck ed., 2006).

${ }^{27} \mathrm{See}$ von HeINTSCHEL-HeINEGG, supra note 25 at $\$ 89$ (a) para. 4.
} 
$\S 239$ b constitutes a serious violent offense endangering the state. These provisions apply to a person who intends to: (1) Impair, and who is capable of impairing, the existence or security of a state or an international organization; or (2) abolish, rob of legal effect, or undermine constitutional principles of the Federal Republic of Germany. This is referred to as the state protection clause. ${ }^{28}$

\subsection{The Individual Preparatory Acts Pursuant to § 89a II, IIa StGB}

Section 89a II, IIa StGB enumerates four distinct and autonomous alternatives of a preparatory act. First, pursuant to $₫ 89$ a II No. 1 StGB, the preparatory act of a serious violent offense endangering the state may consist of instructing another person or receiving instruction in the production or the use of firearms, explosives, explosive or incendiary devices, nuclear fission material or other radioactive substances, substances that contain or can generate poison, other substances detrimental to health, special facilities necessary for the commission of the offense, or other skills that can be of use for the commission of an offense under $\$ 89$ a I StGB. Second, a preparatory act may also be realized by means of producing, obtaining for himself or another, storing, or supplying to another weapons, substances, or devices and facilities mentioned under $₫ 89 \mathrm{a}$ II No. 1 StGB. Third, the preparatory acts covered under $\$ 89$ a II No. 3 StGB may entail obtaining or storing objects or substances essential for the production of weapons, substances, or devices and facilities mentioned under $₫ 89$ a II No. 1 StGB.

The 2015 amendment augmented the individual preparatory acts by implementing a fourth alternative. ${ }^{29}$ This ancillary alternative stipulates, pursuant to $\$ 89$ a IIa StGB, that a preparatory act may also be realized by preparing a serious violent offense that endangers the state, for example, by taking steps to leave the Federal Republic of Germany in order to move to a state within whose territory instructions by persons referred to in the first alternative of the preparatory acts in $\$ 89$ a II No. 1 StGB are given-and doing so for the purpose of committing a serious violent offense endangering the state, or for the purpose of committing any act mentioned under the first alternative of the preparatory acts in $\$ 89$ a II No. 1 StGB.

In general, to meet the requirements of the actus reus of $\$ 89 \mathrm{a}$ I, II, IIa StGB, one of the four enumerated preparatory acts must be committed by the perpetrator along with the intent to commit a serious violent offense endangering the state. ${ }^{30}$ An instant temporal or spatial link between the preparatory act and the state endangering offense is not required, as $₫ 89$ a StGB aims to criminalize acts potentially occurring during the preliminary stages of the act of violence. ${ }^{31}$

The actus reus of $\$ 89$ a I, II No. 1, IIa StGB therefore consists of an alleged offender preparing a serious violent offense which endangers the state in violation of $\$ 89$ a I 2 StGB. First, the alleged offender must take steps to leave the Federal Republic of Germany. Second, his or her reason for leaving the state must be to commit a serious violent offense or, alternatively, to instruct another person or to receive instruction in the production or the use of weapons that can be used in the commission of a serious violent offense pursuant to $\$ 89$ a I StGB, or for the purpose of moving to a state within whose territory instructions by persons referred to in $₫ 89$ a II No. 1 StGB.

\section{Subjective Legal Prerequisites (Mens Rea)}

Generally, the mens rea of $\$ 89 \mathrm{a}$ StGB has three intent requirements. ${ }^{32}$ By contrast, $\$ 89$ a I, II No. 1, IIa StGB has two intent requirements. ${ }^{33}$ The triple intent must consist of at least conditional intent regarding the act of preparation mentioned under $\$ 89$ a I StGB, in conjunction

\footnotetext{
${ }^{28}$ See id. at $\$ 89$ (a) para. 5.

${ }^{29}$ See Gesetzesentwurf [Draft Bill], Deutscher Bundestag: DrucKsaChen [BT] 18/4087 at 6 (Ger.).

${ }^{30}$ See JÜrgen Schäfer, MÜnChEner Kommentar ZU STGB, $\$ 89$ (a) paras. 31-32 (3d ed. 2017).

${ }^{31}$ See id. at $\$ 89$ (a) para. 34.

${ }^{32}$ See von Heintschel-HeinegG, supra note 25 at $\$ 89$ (a) para. 26.

${ }^{33}$ See Gesetzesentwurf [Draft Bill], Deutscher BundestaG: DrucKsachen [BT] 18/4087 at 10 (Ger.).
} 
with $₫ 89$ a II, IIa StGB, ${ }^{34}$ with regard to the commission of an offense pursuant to $\$ \$ 211,212$, 239a, 239b StGB. Additionally, direct intent is required with respect to the offense's ultimate suitability to endanger a state. ${ }^{35}$

Within its decision of October 27, 2015, the BGH demanded that the perpetrator recognize the circumstances resulting in the potential endangerment of a state in relation to the direct intent, and that he include them into his will. ${ }^{36}$ The BGH had to decide whether the accused was guilty of the preparation of a serious violent offense which endangered the state pursuant to $\$ 89$ a II No. 1, I StGB. ${ }^{37}$ The accused traveled with her two daughters to Syria to join the family of a Jabhat al-Nusra member as his second wife. ${ }^{38}$ In Syria she then became a sympathizer of the Jabhat al-Nusra. ${ }^{39}$ The family changed their place of residence several times to avoid armed conflicts. ${ }^{40}$ Nonetheless, the accused was instructed by her husband on how to handle machine pistols, a Kalashnikov assault rifle, and hand grenades so as to be able, in the event of an emergency, to defend her family against the fighters of opposing groups or soldiers of the Syrian army. ${ }^{41}$ She also evolved the readiness to use these weapons and kill opposing fighters in the event of an attack. ${ }^{42}$ The prosecution service deemed this behavior to be the preparation of a serious violent offense endangering the state. ${ }^{43}$ The $\mathrm{BGH}$, on the contrary, ruled it to be insufficient for a couple of reasons. ${ }^{44}$ First, not every single act of violence against life per se meets the requirements of the state protection clause of $\$ 89 \mathrm{a}$ I 2 StGB. ${ }^{45}$ The BGH explained that, as a rule, $\$ 89$ a I 2 StGB is not met if these actions intend primarily to protect one's own physical existence by means of purely defensive acts, which are at best indirectly directed against the state. ${ }^{46}$ The accused did not actively partake in armed combat-she even moved several times to avoid such situations-and though she had been instructed by her husband-a preparatory act mentioned under $\$ 89$ a II No. 1 StGB — she was found not guilty by the BGH on the grounds of a lack of direct intent to endanger the Syrian state. ${ }^{47}$ Second, the purpose of $\$ 89$ a StGB is to prosecute terrorists, not to prosecute persons who are instructed by family members to protect their own lives in conflict areas without participating actively in armed combat. ${ }^{48}$ To meet the requirements of $\$ 89$ a I, II No.1, IIa StGB, the offender must, on the one hand, intend to leave the Federal Republic of Germany to enter another state for terrorist purposes and, on the other hand, must intend to commit or prepare to commit a serious violent offense endangering the state. ${ }^{49}$

Therefore, in contrast to the generally required triple intent $\$ 89$ a I, II No.1, IIa StGB requests both parts of the intent to be stronger than conditional and direct intent-for example, the perpetrator has to possess the intention to achieve the success which the law in question seeks to

\footnotetext{
${ }^{34}$ See Bernd von Heintschel-Heinegg, von Heintschel-Heinegg Strafgesetzbuch StGB Kommentar $\$ 89$ (a) para. 31 (42d ed. 2019).

${ }^{35}$ See Nikolaos Gazeas et al., Die neuen Tatbestände im Staatsschutzstrafrecht - Versuch einer ersten Auslegung Der $\$ \$ 89$ A, 89B Und 91 STGB, 29 Neue Zeitschrift Für Strafrecht [NStZ] 596 (2009).

${ }^{36}$ Bundesgerichtshof [BGH] [Federal Court of Justice] Oct. 27, 2015, 69 NEUE JURISTISCHE WOCHENSCHRIFT [NJW] 260 para. 10, 2016.

${ }^{37} I d$. at para. 8.

${ }^{38} I d$. at para. 4.

${ }^{39} I d$.

${ }^{40} I d$.

${ }^{41} I d$.

${ }^{42} I d$. at para. 4.

${ }^{43} I d$. at para. 5.

${ }^{44} I d$. at para. 8.

${ }^{45} \mathrm{Id}$. at para. 11.

${ }^{46} I d$.

${ }^{47} I d$.

${ }^{48} \mathrm{Id}$. at paras. $12-14$.

${ }^{49}$ See Gesetzesentwurf [Draft Bill], Deutscher BundestaG: DruCKSACHEN [BT] 18/4087 at 10 (Ger.).
} 
prevent by penalizing certain actions $\mathrm{s}^{50}$ - whereas conditional intent does not require the perpetrator to strive for the prohibited success but only to deem its occurrence possible. ${ }^{51}$ Additionally, it requires direct intent, which requires the perpetrator's knowledge that his actions will induce the success. ${ }^{52}$ As such, $\$ 89$ a I, II No.1, IIa StGB is narrower, and consequently stricter, regarding its subjective legal prerequisites. As mentioned above, $₫ 89$ a StGB was implemented to punish actions which pertain to the preparation of extreme serious offenses but which do not meet the requirements of $\$ \$ 30,129,129 \mathrm{a}, 129 \mathrm{~b}$ StGB for the lack of a terrorist organization and as a consequence are not punishable. ${ }^{53}$ Although the structure of $\$ 89$ a StGB is designed to restrict the punishable action to departures for terrorist purposes, ${ }^{54}$ it remains problematic under constitutional law to prepone the general commencement of the punishable actus reus to the preparation of the offense. As a consequence, this leap ahead requires strict justification. ${ }^{55}$

\section{The Constitutionality of $\S 89$ a I, II No. 1, IIa StGB}

The Court made the constitutionality of $\$ 89$ a IIa StGB an important subject of its discussions within the decision-making process. In order to be constitutional, a law is required to comply with the constitutional prerequisites of legal certainty and appropriateness. With regard to the constitutionality of $\$ 89$ a I, II No. 1, the BGH had already ascertained that the law is in line with the German constitutional principles ${ }^{56}$ in particular concerning the prerequisite of pursuing a legitimate purpose with regard to legal certainty. ${ }^{57}$ On account of this, the constitutionality of $\S 89$ a I, II No.1 will not be addressed further, but rather we will focus on the constitutionality of $\$ 89$ a II.

Notwithstanding, the assessment concerning the constitutionality of $\$ 89$ a I, II No. 1, the decision that the $\mathrm{BGH}$ made on May $8,2014,{ }^{58}$ needs to be looked at further in this context, especially with regard to potential interactions with former decisions. Within this decision, the BGH stated that the forward displacement of culpability to actions does not exceed the requirement of appropriateness if the reviewing court issues a case-by-case assessment within a restrictive interpretation of this law. ${ }^{59}$ Furthermore, the BGH emphasized that in order to be held criminally responsible, the accused must have had the intention to commit a serious offense that might endanger the state while preparing the act by initially non-illegal actions. It is insufficient if the accused does not possess the strict intent but solely suspects or accepts the possibility of later committing the act in question.

\section{The Prerequisite of Appropriateness}

The prerequisite of appropriateness ${ }^{60}$ of a regulation or decision pertains to a weighing of interests that are protected, and those affected, by the law. The evaluation of a law's appropriateness

\footnotetext{
${ }^{50}$ See Detlev Sternberg-Lieben \& Frank Schuster, Strafgesetzbuch Kommentar $\$ 89$ (a) para. 66 (Adolf Schönke \& Horst Schröder eds., 30th ed. 2019).

${ }^{51}$ See id. at $\$ 89$ (a) para. 72.

${ }^{52}$ See id. at $\$ 89$ (a) para. 68.

${ }^{53}$ See 69 NJW 260 at para. 13.

${ }^{54}$ See Gesetzesentwurf [Draft Bill], Deutscher Bundestag: Drucksachen [BT] 18/4087 at 8 (Ger.).

${ }^{55}$ See VON HeINTSCHEL-HeinegG, supra note 25 at $\$ 89$ (a) para. 1-2.

${ }^{56} \mathrm{See}$ Gesetz zur Verfolgung der Vorbereitung schwerer staatsgefährdender Gewalttaten [Law regarding the Prosecution of Preparation of State-Endangering Offenses] June 30, 2009.

${ }^{57}$ Bundesgerichtshof [BGH] [Federal Court of Justice], May 8, 2014, 67 NeUE JuRISTISCHE WoCHENSCHRIFT [NJW] 3459, 2014.

${ }^{58} \mathrm{Id}$.

${ }^{59}$ See 70 NJW 2928 at para. 1-3.

${ }^{60}$ Bundesgerichtshof [BGH] [Federal Court of Justice] Apr. 19, 1982, 21 NeUE JuRISTISCE WochENSCHRIFT [NJW] 2444, 1982.
} 
is scrutinized based on the four criteria developed by the German Constitutional Court (Bundesverfassungsgericht). These are legitimate purpose (legitimer Zweck), necessity (Notwendigkeit), suitability (Geeignetheit), and reasonability (Angemessenheit). ${ }^{61}$

\subsection{Legitimate Legislative Purpose}

A law that violates an individual's basic right is required to pursue a legitimate legislative purpose. ${ }^{62}$ This principle does not restrict the German legislature to certain purposes and aims, but rather it is predominantly subject to examinations of the state's duty of impartiality. ${ }^{63}$ The German Federal Court of Justice held that prevention of severe offenses endangering the state constitutes a legitimate legislative purpose. ${ }^{64}$

\subsection{Suitability and Necessity}

The prerequisites of suitability and necessity require a law to be deemed suitable and necessary to achieve the stated purpose in order to justify the infringement of a basic right. ${ }^{65}$ Suitability refers to the appropriateness of certain measures or regulations to achieve or further the purpose. ${ }^{66}$ The measures stipulated in $\$ 89$ a IIa StGB are suitable to prevent suspected offenders of violent acts that endanger the state from leaving the Federal Republic of Germany when they are planning to be instructed in another country in how to handle firearms and explosives - which are necessary to commit a violent offense endangering the state ${ }^{67}$ - such as the suspect in the above-mentioned decision. ${ }^{68}$

The constitutional doctrine of necessity requires a measure to be the least severe option in comparison to others to achieve the purpose. ${ }^{69}$ Section 89a IIa StGB is considered to be in line with the prerequisite of necessity, as the Basic Law-Germany's constitution-does not provide another law that could be effective in achieving the stated purpose while being less restrictive to an individual's basic rights stipulated in Article 2(1) of the Basic Law. ${ }^{70}$

It could be countered that criminalization by imposing bans on leaving the country might constitute a less severe infringement to a basic right. Although the effectiveness of such a ban is highly dubitable, this solution could not include suspects who are not known to the authorities before they attempt to leave the country. This means that such a ban could only be imposed on suspects who have already been identified. This is not what the regulation of $₫ 89$ a IIa StGB intends to achieve. Section 89a IIa StGB should cover a wider range of suspects, including unknown offenders. As such, this constitutes a more effective way of protecting the internal state security. ${ }^{71}$

\footnotetext{
${ }^{61}$ Bundesverfassungsgericht [BVerfG] [Federal Constitutional Court] June 6, 1989, 28 NeUE JURISTISCHE WOCHENSCHRIFT [NJW] 159, 1989.

${ }^{62}$ See Stefan Huster \& Johannes Rux, Article 20, in BeCK'SCHER OnLINE-Kommentar zum GrundgesETZ para. 193 (20th ed. 2014).

${ }^{63}$ See id. at art. 20, para. 193.1.

${ }^{64}$ See Puschke, Ausreise als Vorbereitung einer schweren staatsgefährdenden Gewalttat, 70 NEUE JURISTISCHE WOCHENSCHRIFT [NJW] 2928 (2017).

${ }^{65}$ See Christopher Ohnesorge et al., The Constitutionality of $\$ 89$ a of the German Criminal Code (StGB) and the Concept of a Serious Act of Violent Subversion: The German Federal Court of Justice (Bundesgerichtshof), Judgement of 8th May 2014 - 3 StR 243 / 13, 18 GERMAN L.J. 631, 638 (2017).

${ }^{66}$ See B.Grzeszick, Art. 20 GG-Kommentar, Maunz/Düring para. 112 (C.H. Beck ed., 2016).

${ }^{67}$ See 70 NJW 2928 at para. 30.

${ }^{68}$ See 70 NJW 2928 at para. 5.

${ }^{69}$ See Bernd Grzeszick, Article 20, in MAUnZ \& DürInG, GG-Kommentar para. 112 (2016); see also Ohnesorge et al., supra note 65 .

${ }^{70}$ See 70 NJW 2928 at para. 30; Bundesgerichtshof [BGH] [Federal Court of Justice] May 8, 2014, 67 NeUE JURISTISCHE WOCHENSCHRIFT [NJW] 3459, 2014 (Ger.); Grundgesetz [GG] [Basic Law], translation at https://www.gesetze-im-internet.de/ englisch_gg/.

${ }^{71}$ See 70 NJW 2928 at para. 30.
} 
In view of the aforementioned arguments and concerning the prerequisites of necessity and suitability, there are seemingly no grounds for suspecting that the German legislature acted ultra vires with regard to its legislative powers when creating $\$ 89 \mathrm{a} I \mathrm{Ia}$ StGB. ${ }^{72}$

\subsection{Reasonability}

Ultimately, the requirement of reasonability, also referred to as the principle of proportionality, must be met. In order to meet this prerequisite, a law's intensity and the way it affects the individual's right or rights must not be disproportionate to the affected right. ${ }^{73}$ The legally protected good, for example, the law's purpose, must be of such a great importance that it justifies an infringement to an individual's basic right protected by the Basic Law. ${ }^{74}$

The evaluation of the principle of proportionality is not bound to imposed standards, and it therefore must be assessed individually by balancing opposing interests. ${ }^{75}$ With regard to $\$ 89$ a IIa $\mathrm{StGB}$, the criminalization of leaving the country with the intention of being instructed in certain violent measures aimed at endangering a state's security constitutes the infringement of an individual's basic right in Article 2(1) of the Basic Law. This is balanced against the state's security as the legally protected good. As a state's security is considered a protected right of great importance, adequate proportionality can be assumed.

Opponents criticize that criminalizing the act of leaving the country to prepare an offense against the state is criminalizing the preparation of the preparation of an offense. This very early point of criminalization is justified by the categorization of the offense as an Unternehmensdelikt, meaning that the act of the offense is the main reason for the punishment. This results in the fact that the offense is already punishable, even if the act itself is not fulfilled but remains at the attempt stage. In order to prevent an unjustified general ban on leaving the country, however, the suspected offender is required to act with the aforementioned dual intent. ${ }^{76}$ This includes the intention to leave the country and commit or prepare a serious violent offense endangering the state. ${ }^{77}$

Assessing the constitutionality in the case at hand, ${ }^{78}$ the suspect acquired the requisite explosive materials to construct a bomb. Although this is solely the preparation of the preparatory act, the intention to leave the country to be instructed and to at least further the offense endangering the state outlines a solution to the highly criticized early stage of criminalization, as the intention of endangering the state to that extent in correlation with the first preparatory actions depicts a danger to the legally protected interest of the state's security. ${ }^{79}$

Furthermore, it must be stated that a suspect's attempt to leave the Federal Republic often constitutes the last possibility for the state to apprehend this suspect and to prevent them from further radicalization and affirming their convictions and attitudes. ${ }^{80}$ Therefore, the Federal Court of Justice deemed $\$ 89$ a IIa StGB constitutional, although perhaps marginally. Nonetheless, it is certainly not considered to be in excess of the legislature's authorization. ${ }^{81}$

Aside from that, there has been the accusation that $\$ 89$ a IIa StGB bases its penalization solely with the offender's attitude (Gesinnungsstrafrecht). ${ }^{82}$ This accusation is, however, unjustified

\footnotetext{
${ }^{72} I d$.

${ }^{73}$ See Ohnesorge et al., supra note 65, at 638; Huster \& Rux, supra note 62, at para. 193.1.

${ }^{74}$ See Huster \& Rux, supra note 62, at para. 197.

${ }^{75}$ See id. at art. 20 para. 197.

${ }^{76}$ See Gesetzesentwurf [Draft Bill], Deutscher Bundestag: DrucKSACHEN [BT] 18/4087 at 10 (Ger.).

${ }^{77} \mathrm{Id}$.

${ }^{78}$ See 70 NJW 2928 at para. 30.

${ }^{79} I d$. at para. 35 .

${ }^{80} \mathrm{See}$ Ulrich Sieber \& Benjamin Vogel, Terrorismusfinanzierung, MAX PlanCK InSTITUT ZUR ERFORSCHUNG VON KRIMINALITÄT, SICHERHEIT UND RECHT at para. 141 (2015), https://csl.mpg.de/en/publications/terrorismusfinanzierung/.

${ }^{81}$ See Bundesverfassungsgericht [BVerfG] [Federal Constitutional Court] Apr. 24, 2013, 66 NEUE JURISTISCHE WOCHENSCHRIFT [NJW] 1215, 2013 (Ger.).

${ }^{82}$ See 70 NJW 2928.
} 
because it is not unconstitutional to penalize an objectively neutral action in correlation with the aforementioned mens rea, owing to the fact that the intention to endanger does not substantiate criminalization based solely upon the offender's attitude. ${ }^{83}$ This criticism would be justified if the offender's intent was not manifested in any action, ${ }^{84}$ which is not the case here. Section $89 \mathrm{a}$ IIa requires the suspect to undertake the stipulated act of leaving the country as a preparation to the offense endangering the state. ${ }^{85}$

\section{The Prerequisite of Legal Certainty}

Article 103 II of the German Constitution contains the principle of nulla poena sine lege-meaning, an offense is not punishable if it is not established by a legislative regulation. This principle includes the prerequisite of legal certainty ${ }^{86}$ and a prohibition of analogy in criminal law. ${ }^{87}$

This principle contains the prerequisite of legal certainty-before the commission of an offense-considering an ascertainment of the punishable act and the impending sentence. ${ }^{88}$ "Therefore, the legislature is committed to paraphrasing the conditions of criminal liability in such a precise way that the consequence and area of application of the criminal offence is distinguishable and determinable by an interpretation of the legal provision." 89 This prerequisite mainly addresses the offenders, that is, those affected by the questionable law, to provide them with certainty when evaluating whether their behavior is criminally punishable conduct. ${ }^{90}$ It has been stated that there is no indication that $\$ 89$ a IIa StGB is not in line with the prerequisite of legal certainty, as there are no significant differences to the previously ascertained legal certainty of $\$ 89$ a StGB.

\section{Interim Result on Constitutionality}

Although this topic has been hotly and critically debated as being a "criminalization of the preparation of the preparation," $" 11$ the Federal Court of Justice held that $\$ 89$ a IIa StGB is in accordance with the principles of legal certainty and appropriateness set out in the German Constitution and, therefore, is constitutional.

With reference to the aforementioned decision by the BGH from May 8, 2014, ${ }^{92}$ the assessment of $\$ 89$ a IIa StGB can be seen as an interaction. The circumstances of the decision from April 2017 can be compared to those of the decision from May 2014. The accused prepared for serious offenses endangering the state, which can be assessed as establishing the culpability. This is true, even though the particular actions themselves were not forbidden, and they did not exceed the requirement of appropriateness because they were committed with the required special intent to commit the later offense.

\footnotetext{
${ }^{83}$ See 67 NJW 3459.

${ }^{84}$ See SIEBER \& VOGEL, supra note 80 at paras. $140-143$.

${ }^{85}$ See 67 NJW 3459.

${ }^{86} \mathrm{Id}$.

${ }^{87}$ See Bundesverfassungsgericht [BVerfG] [Federal Constitutional Court] Mar. 19, 2007, 60 NEUE JURISTISCHE WOCHENSCHRIFT [NJW] 1666, 2007 (Ger.).

${ }^{88}$ See Henning Radtke \& Andrea Hagemeier, Article 103, in BECK’SCHER OnLINE-KOMMENTAR ZUM GrundGESETZ para. 18 (20th ed. 2014).

${ }^{89} \mathrm{See}$ Ohnesorge et al., supra note 65 at 635; Jarass \& Pieroth, BECK'SCHER ONLINE-KOMMENTAR ZUM GRUNDGESETZ supra note 88 , at Art. 103 para 48 .

${ }^{90}$ See Andreas Ransiek, p. 55 (1989) (Dissertation, University of Heidelberg) (on file with author); Winfried Hassemer \& Walter Kargl, Strafgesetzbuch para. 14 (Urs Kindhäuser, Ulfrid Neumann \& Hans-Ullrich Päffgen eds., 5th ed. 2017).

${ }^{91}$ See Jens Puschke, Der Ausbau des Terrorismusstrafrechts und die Rechtsprechung des Bundesgerichtshof, HUMANISTISCHE UNION, Iss. 4, 2015, at 457, 459.

${ }^{92}$ See 70 NJW 2928 at paras. $1-3$.
} 


\section{Application to the Case}

\section{Actus Reus}

As mentioned above, the accused was found guilty of two violations of $₫ 89$ a IIa, I, II No. 1 StGB. ${ }^{93}$ The first violation was committed on June 24, 2015, when the accused left the territory of the Federal Republic of Germany by entering the sovereign territory of Turkey. ${ }^{94}$ The second violation was perpetrated on October 10, 2015, as the accused unsuccessfully attempted to leave Germany for Turkey on his way to Syria. ${ }^{95}$ The accused entered the chargeable phase of an attempt of $\S 89$ a IIa, I, II No. 1 StGB by presenting himself at the departure control. ${ }^{96}$ The perpetration of a criminal offense generally commences when the commission of the offense starts. This refers to actions by the offender that are qualified to culminate without any further additional actions and without any disturbance in the realization of the offense. ${ }^{97}$ This phase is entered into, in the case of air travel, as soon as the commencement of the flight is imminent which, as a rule, is at the check-in. ${ }^{98}$ Consequently, the mere attempt to leave Germany on October 10, 2015, sufficed to constitute the first requisite prerequisites of the actus reus of $\$ 89$ a IIa, I, II No. 1 StGB: Namely, attempting to leave Germany to move to another state, Syria, within whose territory instructions are given by persons referred to in the first alternative of the preparatory acts in $\$ 89$ a II No. 1 StGB. ${ }^{99}$

The required preparatory act pursuant to $\$ 89$ a IIa StGB had been met with regard to both intended departures. Nonetheless, these preparatory acts must also serve as the preparation of a serious violent offense endangering the state pursuant to $\$ 89 \mathrm{a}$ I StGB. The accused planned to participate in combat training and combat operations of an Islamist organization. ${ }^{100}$ The intended participation in armed combat in Syria, which aimed at killing soldiers of the Syrian government troops, is a subset of the offenses against life mentioned in the state protection clause, namely $\$ \$ 211,212$ StGB. ${ }^{101}$ The primary objection of this fighting was to destroy the present Syrian state system. ${ }^{102}$ As a result, these planned offenses against life are suitable, as required by the state protection clause, to impair even the existence or, at the very least, the security of the Syrian state. ${ }^{103}$ Therefore, the attempts to leave Germany constitute a preparatory act pursuant to $\$ 89$ a IIa StGB providing the preparation of a serious violent offense endangering the state pursuant to $₫ 89$ a I StGB. The statutory actus reus of $\$ 89$ a IIa, I, II No. 1 StGB was therefore fulfilled.

\section{Mens Rea}

The actus reus must be committed with a corresponding state of the mind proscribed by law. With regard to $\$ 89$ a IIa StGB, this is a double intent. The accused left Germany willfully and knowingly, with emphasis on willfully, for the purpose of entering another state, Syria, wherein the instruction of persons mentioned under $\$ 89$ a II No. 1 StGB is provided in terrorist training camps. ${ }^{104}$ This state of mind constituted the first required half of the necessary double intent. ${ }^{105}$ The second half

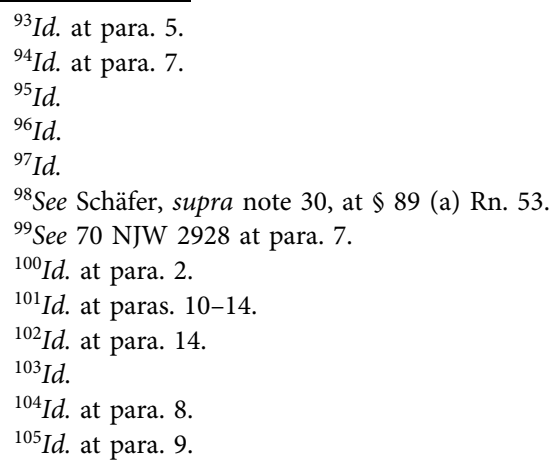


refers to the perpetrator's intention in connection with his departure from Germany and entry into the respective country: To commit a serious violent offense endangering the state or to commit actions mentioned under $\$ 89$ a II No. 1 StGB. As the accused's intention was to undergo training in how to handle firearms and explosives, he intended to commit actions mentioned under $\$ 89$ a II No. 1 StGB, thereby fulfiling the second half of the double intent under $\$$ 89a IIa StGB. ${ }^{106}$ Therefore, the requirements of the mens rea and the actus reus were both met, which resulted in the conviction of the accused for two infringements of $\$ 89 \mathrm{a}$ IIa in conjunction with $\$ 89$ a I, II Nr. 1 StGB.

\section{E. Conclusion}

Punishing people without the existence of an outwardly aimed ratified preparatory act has been criticized, particularly as the regulatory content of $\$ 89 \mathrm{a}$ of the German Criminal Code is considered insufficient with regard to providing behavioral orientation. Moreover, the intention of endangering the state, because the only threat which could be considered comes from the Syrian state, has been questioned by the BGH. Section 89a IIa StGB has been deemed constitutional, operating within the prohibition of any excessiveness. In particular, the protection of the democratic and liberal order by effectively combating terrorist threats must be granted higher constitutional significance. ${ }^{107}$ This stands true, even if this regime makes use of criminal methods to enforce or to maintain its rule. In general, a line can only be drawn where the fight against an unjust regime would be justified under principles of international contract or customary international law. ${ }^{108}$

\footnotetext{
${ }^{106} I d$. at para. 8 .

${ }^{107} \mathrm{Id}$.

${ }^{108} I d$.
}

Cite this article: Zaunseder A-S, Heblik M (2020). The Constitutionality of $\$ 89$ a IIa of the German Criminal Code and the Concept of a Serious Violent Offense Endangering the State: The German Federal Court of Justice Decision of April 6, 2017 -3 StR 326/16. German Law Journal 21, 775-786. https://doi.org/10.1017/glj.2020.33 